\title{
Application of peer editing method in English composition class: A positive outcome
}

\author{
MST. FARHANA FERDOUSE
}

\section{Introduction:}

In the field of English language teaching, there exist four basic skill areas namely reading, writing, listening and speaking. Each area plays a significant role in the development of the learners. Writing is a major skill area and is considered a productive skill. Writing increases the student's personal knowledge and selfesteem and encourages learning in all subject areas, by employing auditory, visual and kinesthetic systems all at once. Most importantly, writing contributes significantly to improve reading skills, vocabulary application, and therefore speaking ability. Peer editing is a step in the writing process that helps students evaluate and improve the quality of their written work in many ways. It is a major process in academic writing. It involves students to take part in editing each other's writing, highlighting the strengths and weaknesses in their writing. Peer editing helps to build students' sense of identity and provides them with chances to learn from each other and enhance their awareness of their abilities and knowledge alike. This paper discusses the advantages of peer editing, guidelines for in-class editing, few drawbacks, and further suggestions on how to apply peer editing method effectively in English composition class for a positive outcome.

\section{Literature Review:}

Second language writing instruction has gradually evolved from the traditional product oriented approach to the process writing approach over the last three decades. Instead of focusing solely on formal accuracy and the final product of writing, process approach instills "greater respect for individual writers and for the writing itself" (Hyland, 2003, p.17). It is a recursive procedure which advocates prewriting activities, encourages peer editing and requires multiple drafts. Peer editing is a crucial component in multi drafted process-oriented writing instructions. The use of peer editing process has been generally supported in the literature as a 
"potentially valuable aid for its social, cognitive, affective, and methodological benefits" (Rollinson, 2005, p.23). The beneficial impact and effectiveness of peer editing have been substantiated by a number of empirical studies; for example, Min (2006), Tsui \& Maria (2000). It has been claimed that peer readers can provide useful feedback, as they revise effectively on the basis of feedback they receive from peer editors. Peer feedback can be seen as complementary to teacher feedback in that it is more specific, and that by reading others writing as critical readers, students could become more critical readers and editors of their own writing.

\section{Advantages of applying peer editing method:}

From a socio-cognitive perspective, peer response can be seen as a formative developmental process that gives writers the opportunities to discuss their texts and discover others' interpretations of them. Peer editing allows students to share ideas regarding the topics of their writing, the different styles and structures and the editing methods and techniques. It also creates an atmosphere of co-operation and enthusiasm among students. They feel equal in one situation where they are helping each other to produce better results. In this regard, peer editing plays an important role in developing students' independence and raising their self esteem and confidence in their abilities. In addition, peer editing enhances students' responsibility by allocating them a role similar to the teacher's to spot mistakes and help to fix them. Students in this case benefit by identifying strengths and weaknesses in their own writing as well as in their peers'. The process of looking at each other's piece of writing reinforces their editing skills and makes them aware of such criteria the next time they write. They read with a critical eye which helps them develop their critical thinking skills and improve their writing skills by being exposed to different writing types.

As for the benefits of peer editing on teachers' part, it decreases the amount of their paperwork. Instead of marking whole class papers of first drafts, teachers will look at the papers after they have been reviewed by the students' peers. This would give the teacher the chance to spot higher level mistakes that could also indicate the areas that need working out with the whole class. The teacher could also be observant as to praise strong editors who will eventually become highly appreciated by their peers. Their highlighted thoroughness and attention to detail will become qualities of positive competition in the 
classroom. The other students will seek the same as to become good writers and editors and hence will have their works completed more often.

Peer editing method will also increase their overall fluency and similarly improve their reading comprehension because students learn more when they personally apply principles without being forced by higher authorities. At the end they will notice that their writing skill is indeed improved than before.

\section{Classroom Application:}

\section{Procedural Guidelines:}

Before starting the process of peer editing, there are some steps a teacher should follow and some issues to keep in mind. Peers should be divided into several groups so that they can work together on their papers and, the teacher should determine it considering the size of the class. Another point to be taken on account of is whether the teachers choose the peers or they let students choose for themselves. This should be decided upon earlier so that it does not waste the class time nor cause any dissatisfaction among the students. After settling down the specific peers there are two ways to distribute papers among students. One way is to mix all the papers and then allocate them randomly so that students get a chance to move around and meet their peers to discuss their feedback. The other way is to

let students exchange each other's papers within their groups. This will depend on the number of students in the class. Moreover, students should be provided with specific guidelines for the editing process through which they can focus their editing of each other's papers. Editing symbols should also be well known to students so that they apply them adequately. The feedback form should address the content as well as the accuracy of the written work. It will also provide them with a sense of appreciation and support their self esteem. It will enhance their confidence and make them feel responsible for the task they are assigned. It will of course ease the process of knowing who peered up with whom to be able to meet later and discuss. Teacher should stress that students take it seriously and read through the whole paragraph before spotting the mistakes to give them a better understanding of what is written. The second round involves scanning the paragraph and finding 
the mistakes. They should not fix any mistakes but only underline them and write the editing symbols on top of the words.

\section{Code for error correction:}

\begin{tabular}{|c|c|c|c|}
\hline Symbol & Type of Error & Symbol & Type of error \\
\hline$/$ & Unnecessary word & Pro & Pronoun \\
\hline$?$ & Meaning unclear & Ps & Parallel structure \\
\hline$\wedge$ & Word missing & Rc & Relative clause \\
\hline Art & Article & Cap & Capital letter needed \\
\hline Ro & Run-on & c/nc & Countable/non-countable noun \\
\hline Cs & Comma splice & Sv & Subject-verb agreement \\
\hline T & Tense & Frag & Sentence fragment \\
\hline Vf & Verb form & Ts & Topic sentence \\
\hline P & Punctuation & Wf & Word form \\
\hline Pre & Preposition & & \\
\hline
\end{tabular}

This will give the writers a hint of the kind of errors and make it easy for them to fix it later. After having papers along with feedback forms, the students should start fixing their mistakes using the hints provided through the editing symbols and the notes and comments in the feedback forms. In some cases, students might not be clear about some comments or suggestions and in such a case they should consult their editors. In so many cases it may happen that student writer is correct and the student editor makes a mistake. So student writer should discuss their viewpoints on the mistakes they are not convinced with. To assist students to fix their mistakes, a dictionary and a grammar book plus the study notes are the best companions. They can always go back to their editors and check the possible ways of editing or even ask other students in their groups to give them a hand. Moreover the teacher should relax the time limit so that the editors can work efficiently. Teacher should carefully consider this period when the students will prepare the edit sheet. The amount of time allotted for editing depends on the length and nature of the writing assignment and the content of the edit sheet. For a 500 word composition, editors 
can be given 20 minutes to edit the papers. Some students at first may not complete all the questions but gradually they will become more proficient and will work faster.

\section{Areas of suggestions for the students:}

Before practicing peer editing method, teacher should give his/her students a clear conception about the necessary requirements of writing a good paragraph. In a paragraph-

- $\quad$ Title should address the topic.

- Details or explanations should support the topic.

- Topic sentences should be focused and specific.

- Connectors have to be used thoroughly and correctly.

- $\quad$ Capitalization should be used where necessary.

- $\quad$ Spelling mistakes should be fixed and not repeated.

- Singular/plural nouns should be correctly used.

- Punctuation marks should be used properly.

- Prepositions should be used correctly.

\section{Case Study:}

Setting:

This study was conducted in a course titled 'English Composition' in Summer 2009 in Stamford University Bangladesh. The participants (18 in number) were the students of BBA. The objectives of the course were to help students fully develop their abilities in writing in English. The course began with sentence-level, grammatical practices and then paragraph-level writing and it ended with the production of different types of paragraphs including description, cause and effect and compare \& contrast. The classes were in the form of lectures, brainstorming, group discussion, in class and out of class writing and peer review activities. This was not the students' first experience with peer review. In the first 10-12 classes of the course, the teacher had been encouraging them to do peer-editing for each 
other. Those who did well in peer-editing were praised in class. The teacher sometimes showed the whole class PowerPoint slides with examples demonstrating how to edit a composition successfully and how to comment on the particular errors. It was for the first time the teacher made peer preview performance part of the final score. The final score of the course comprised of -

\begin{tabular}{ll} 
Mid-Term & $-30 \%$ \\
Final Term & $-30 \%$ \\
Class Test (2) & $-20 \%$ \\
Assignment & $-10 \%$ \\
Attendance & $-10 \%$ \\
\hline Total & $100 \%$
\end{tabular}

The teacher counted their editing proficiency as 'Assignment' to motivate the students. The teacher rated the students on the basis of to the written feedback they gave to their group members. These rules were made clear to the students at the beginning of the trimester. The teacher adopted and modified the "writing cycle" suggested by Tsui \& Maria (2000) in designing his class. Tsui \& Maria (2000) described the writing cycle as follows: Topic selection, brainstorming, writing the first draft, giving and receiving peer comments, revising writing the second draft, second round of peer comments, further revision for writing a third draft, teacher comments (as a normal activity of the writing process), then final revision to write the fourth draft. However, in order to observe the effects of peer comments, only the First drafts of the paragraphs were counted for data analysis. 


\section{The Writing Cycle}

\begin{tabular}{|c|}
\hline Topic Selection \\
(Teacher and students) \\
Brainstorming \\
Writing first draft \\
Peer comments \\
(Focus on content \& organization+ peer editing sheet \\
Writing the second draft \\
Peer comments \\
(Focus on content \& organization+ peer editing sheet \\
Third draft \\
Teacher's comments \\
(Focus on content \& organization and forms) \\
\hline
\end{tabular}

\section{Participants:}

Before starting the experimental classes, the teacher took a 'Diagnostic Test' for assessing student's English proficiency. The result of the test was used for grouping the participants into three different groups of six in each. The students were grouped by mixed ability and shared ability levels (Richards \& Lockhart, 2000). In order to mix the students' levels of proficiency, three students who obtained highest scores were mixed with the three lowest proficiency students (group 1); three second highest proficiency students were mixed with three second lowest proficiency students (group 2), and finally, the six medium proficiency students were put together (group 3). After the teacher determined the three groups, the group members selected a monitor for each group. 


\section{Participant's Information}

\begin{tabular}{|c|c|c|c|}
\hline Group & Student's Name & Role & $\begin{array}{c}\text { Marks Obtained in } \\
\text { Diagnostic Test }\end{array}$ \\
\hline \multirow{6}{*}{1.} & Atikur Rahman & G.M & 4.5 \\
\hline & Selima Hossain & G.M & 6.75 \\
\hline & Rubina Islam & Monitor & 4.75 \\
\hline & Mushfiqur Rahman & G.M & 4.25 \\
\hline & Tamanna Sayed & G.M & 6.5 \\
\hline & Gulshan Ara & G.M & 6.75 \\
\hline \multirow{6}{*}{2.} & Amina Khatun & G.M & 5.25 \\
\hline & Dilruba Jahan & G.M & 5 \\
\hline & Selim Morshed & G.M & 6.25 \\
\hline & Arif Islam & Monitor & 5 \\
\hline & Kaium Hossain & G.M & 6 \\
\hline & Habibur Rashid & G.M & 6.25 \\
\hline \multirow{5}{*}{3.} & Shanaj Parveen & G.M & 5.75 \\
\hline & Abdur Rahim & G.M & 5.5 \\
\hline & Aminul Islam & Monitor & 6 \\
\hline & Ziaur Rahman & G.M & 5.75 \\
\hline & Mamunur Rashid & G.M & 5.25 \\
\hline
\end{tabular}




\begin{tabular}{|l|l|l|l|}
\hline & Zakir Hossain & G.M & 5.5 \\
\hline
\end{tabular}

\section{Procedure:}

This study was conducted in the $2^{\text {nd }}$ half of the trimester in the class. All the writing assignments were conducted with a multi-draft process. After writing first drafts, the students were required to read group members' paragraphs and to give each other written feedback that could be used for revision.

\section{Feedback form for the peer editors:}

Name of the student writer : $\quad$ Name of the student editor:

ID: ID:

Instruction: Your comments will be used by the author to rewrite his or her paper. Be as detailed and helpful as possible. Write all comments on this sheet (peer editors are allowed to correct the errors).

1) Is there any specific topic sentence? Yes $\square$ No $\square$

Specific comment:

2) Do all the details support the topic sentence? Yes $\square$ No $\square$

Specific Comment:

3) Is the concluding sentence appropriate (Concluding Sentence should restate the topic sentence)? Yes $\square$ No $\square$

Specific Comment:

4) Is there any grammatical errors? Yes $\square$ No $\square$

Specific comment: 
5) What sort of grammatical errors did you trace?

Types of error: Number of errors

6) Have you made any correction? Yes $\square$ No $\square$

How many?

7) Have you taken any help from your teacher? Yes $\square$ No

How many Times:

8) Do you have any further suggestions to improve this paragraph?

Yes $\square$ No $\square$

If your answer is yes say why:

After having received the feedback from their classmates, the students revised and wrote a second draft. The teacher then read the second draft and gave students additional feedback. Finally, the students revised again and wrote their third draft. To probe into the students' revision process, teacher chose Group 1 (totaling 6 students) from the three original groups as participants in this study.

\section{Data collections:}

Data Collection 1st Draft (1 ${ }^{\text {st }}$ paragraph): Table: 1

\section{Total number of papers 6}

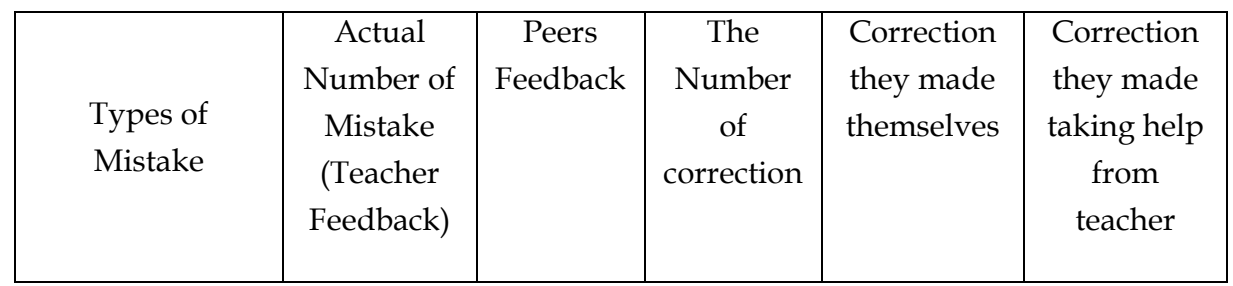




\begin{tabular}{|c|c|c|c|c|c|}
\hline Sp & 33 & 24 & 14 & 5 & 9 \\
\hline Sv & 17 & 13 & 8 & 3 & 5 \\
\hline Frag & 14 & 9 & 4 & 1 & 3 \\
\hline Run-on & 13 & 9 & 5 & 1 & 4 \\
\hline Cap & 20 & 16 & 14 & 11 & 3 \\
\hline Pre & 21 & 17 & 11 & 4 & 7 \\
\hline Tp & 4 & 2 & 0 & - & - \\
\hline Sp sent. & 18 & 9 & 3 & 0 & 3 \\
\hline Concluding sent & 5 & 3 & 2 & 0 & 2 \\
\hline
\end{tabular}

\section{Student - teacher conferences (One to One):}

After the first round commenting on the descriptive paragraph, the teacher had a close look at the comments of each student and arranged one-on-one studentteacher conferences for 10 to 15 minutes for helping the students to write and understand the commentaries properly and work accordingly. Some good comments of other students were also shown as models. Furthermore, during the student-teacher conferences, the teacher helped the students' to solve problems regarding unclear comments they received from their peers and also explained some problems that the group members did not know. The teacher also helped the students to clarify what kind of idea they really wanted to express and confirmed this grammatical point.

Data Collection 1st Draft (2nd paragraph): Table: 2

Total number of papers 6 


\begin{tabular}{|c|c|c|c|c|c|}
\hline Types of Mistake & $\begin{array}{c}\text { Actual } \\
\text { Number of } \\
\text { Mistake } \\
\text { (Teacher } \\
\text { Feedback) }\end{array}$ & $\begin{array}{c}\text { Peers } \\
\text { Feedback }\end{array}$ & $\begin{array}{c}\text { The } \\
\text { Number } \\
\text { of } \\
\text { correction }\end{array}$ & $\begin{array}{l}\text { Correction } \\
\text { they made } \\
\text { themselves }\end{array}$ & $\begin{array}{l}\text { Correction } \\
\text { they made } \\
\text { taking } \\
\text { help from } \\
\text { teacher }\end{array}$ \\
\hline$S p$ & 11 & 10 & 10 & 5 & 5 \\
\hline Sv & 11 & 9 & 8 & 5 & 3 \\
\hline Frag & 9 & 7 & 4 & 3 & 1 \\
\hline Run-on & 10 & 6 & 4 & 3 & 1 \\
\hline Cap & 12 & 12 & 11 & 9 & 2 \\
\hline Pre & 13 & 11 & 9 & 6 & 3 \\
\hline $\mathrm{Tp}$ & 3 & 3 & 1 & - & 1 \\
\hline Sp sent. & 11 & 10 & 9 & 2 & 7 \\
\hline Concluding sent & 3 & 3 & 2 & 2 & - \\
\hline
\end{tabular}

Data Collection 1st Draft (3rd paragraph): Table: 3

Total number of papers 6

\begin{tabular}{|c|c|c|c|c|c|}
\hline \multirow{3}{*}{ Types of Mistake } & $\begin{array}{c}\text { Actual } \\
\text { Number of } \\
\text { Mistake } \\
\text { (Teacher } \\
\text { Feedback) }\end{array}$ & Feedback & $\begin{array}{c}\text { The } \\
\text { Number } \\
\text { of } \\
\text { correction }\end{array}$ & $\begin{array}{c}\text { Correction } \\
\text { they made } \\
\text { themselve }\end{array}$ & $\begin{array}{c}\text { Correction } \\
\text { they made } \\
\text { taking } \\
\text { help from } \\
\text { teacher }\end{array}$ \\
\hline
\end{tabular}




\begin{tabular}{|c|c|c|c|c|c|}
\hline Sp & 5 & 5 & 5 & 4 & 1 \\
\hline Sv & 3 & 3 & 3 & 3 & - \\
\hline Frag & 4 & 3 & 3 & 2 & 1 \\
\hline Run-on & 6 & 4 & 4 & 2 & 2 \\
\hline Cap & 5 & 5 & 5 & 4 & 1 \\
\hline Pre & 8 & 7 & 6 & 5 & 1 \\
\hline Tp & 1 & - & - & - & - \\
\hline Sp sent. & 6 & 3 & 2 & 2 & - \\
\hline Concluding sent & 2 & 1 & 1 & - & \\
\hline
\end{tabular}

\section{Result analysis:}

The data collected from the $1^{\text {st }}$ drafts of $1^{\text {st }}, 2^{\text {nd }} \& 3^{\text {rd }}$ paragraphs prove that students incorporated a great effort to edit their peer's papers resulting tremendous peer feedback into the revision which gradually helped them to become quality writers. Their progress from $1^{\text {st }}$ paragraph to $2^{\text {nd }}$ paragraph and from $2^{\text {nd }}$ paragraph to $3^{\text {rd }}$ paragraph is really remarkable (which is summarized in table 4 ). In the 1st draft of the $1^{\text {st }}$ paragraph, their total grammatical mistakes were 118; peer editors found out 88 errors, they corrected 56 errors, 25 by themselves and 31 taking help from the teacher. In the $1^{\text {st }}$ draft of the $2^{\text {nd }}$ paragraph, their total errors were 66 , peers' feedbacks were 55, and they corrected 46 errors, whereas they corrected 31 errors by themselves and 15 by taking help from the teacher. In the $1^{\text {st }}$ draft of the $3^{\text {rd }}$ paragraph, the total numbers of errors were 31, student's feedback were 27 . Peer editors corrected 26 errors, 20 by themselves and 6 taking help from the teacher. The result of the data analysis clearly revealed the fact that as much as the students were getting involved in peer editing process, their capability of writing and editing were improving tremendously, whereas the number of errors were 
decreasing rapidly. Though most of the revisions and corrections were of surfacelevel, the effort students made in the revising process still represents "a cognitive and linguistic effort that needs to be acknowledged" (Villamil \& De Guerrero, 1998, p.505). It should also be noted that though peer review activities cannot guarantee the overall improvement in a piece of writing, students can become more critical readers and revisers through reading others writings critically. Moreover, here the teacher was no more a silent observer; rather his/her active participation in the process brought a new dimension in teaching and learning process. Through applying the process, the teacher made an opportunity for students to talk to her openly which made the class more interactive and effective as well.

Overall Progress: Table: 4

\begin{tabular}{|c|c|c|c|c|}
\hline $\begin{array}{l}\text { Number of } \\
\text { classes } \\
\text { (Group 1) }\end{array}$ & $\begin{array}{l}\text { Error findings and } \\
\text { correction }\end{array}$ & $\begin{array}{c}\text { Gramma } \\
\text { tical } \\
\text { errors }\end{array}$ & $\begin{array}{l}\text { Errors } \\
\text { on } \\
\text { conte } \\
\text { nt }\end{array}$ & $\begin{array}{c}\text { Overall progress } \\
\text { (Positive/ } \\
\text { Negative) }\end{array}$ \\
\hline \multirow{5}{*}{$\begin{array}{l}1^{\text {st }} \text { draft of } 1^{\text {st }} \\
\text { paragraph } \\
\text { (Practiced in } 1^{\text {st }} \\
2 / 3 \text { classes) }\end{array}$} & $\begin{array}{l}\text { Actual number of } \\
\text { errors }\end{array}$ & 118 & 27 & \multirow{5}{*}{ Positive } \\
\hline & Student's Feedback & 88 & 14 & \\
\hline & $\begin{array}{l}\text { Number of } \\
\text { correction } \\
\text { made }\end{array}$ & 56 & 5 & \\
\hline & $\begin{array}{l}\text { Correction they } \\
\text { made by themselves }\end{array}$ & 25 & 0 & \\
\hline & $\begin{array}{ll}\text { Correction } & \text { they } \\
\text { made taking help } \\
\text { from teacher }\end{array}$ & 31 & 5 & \\
\hline $1^{\text {st }} \mathrm{draft}$ of $2^{\text {nd }}$ & Actual number of & 66 & 17 & \\
\hline
\end{tabular}




\begin{tabular}{|c|c|c|c|c|}
\hline \multirow{5}{*}{$\begin{array}{l}\text { paragraph } \\
\text { (practiced in } \\
\text { next } 2 / 3 \\
\text { classes) }\end{array}$} & errors & & & \multirow{5}{*}{ Positive } \\
\hline & Student's Feedback & 55 & 16 & \\
\hline & $\begin{array}{l}\text { Number } \quad \text { of } \\
\text { correction they } \\
\text { made }\end{array}$ & 46 & 12 & \\
\hline & $\begin{array}{l}\text { Correction they } \\
\text { made by themselves }\end{array}$ & 31 & 4 & \\
\hline & $\begin{array}{ll}\text { Correction } & \text { they } \\
\text { made taking help } \\
\text { from teacher }\end{array}$ & 15 & 8 & \\
\hline \multirow{5}{*}{$\begin{array}{l}1^{\text {st }} \text { draft of } 3^{\text {rd }} \\
\text { paragraph } \\
\text { (practiced in } \\
\text { last } 2 / 3 \text { classes) }\end{array}$} & $\begin{array}{l}\text { Actual number of } \\
\text { errors }\end{array}$ & 31 & 9 & \multirow{5}{*}{ Positive } \\
\hline & Student's Feedback & 27 & 4 & \\
\hline & $\begin{array}{l}\text { Number of } \\
\text { correction they } \\
\text { made }\end{array}$ & 26 & 3 & \\
\hline & $\begin{array}{l}\text { Number of } \\
\text { correction they } \\
\text { made by themselves }\end{array}$ & 20 & 2 & \\
\hline & $\begin{array}{ll}\text { Correction } & \text { they } \\
\text { made taking } & \text { help } \\
\text { from teacher } & \end{array}$ & 6 & 1 & \\
\hline
\end{tabular}




\section{Questionnaire for students:}

Just before finishing the course, students were asked to attend a questionnaire session. Their commentary revealed the fact that they enjoyed the whole process a lot. It created a great opportunity for them to improve their writing skill along with other three skills like reading, speaking and listening as well. Though few of the students faced some problems, their overall impression about peer editing process was positive:

\begin{tabular}{|c|c|c|c|c|}
\hline $\begin{array}{l}\text { Total number } \\
\text { of Students }\end{array}$ & Question & Yes & No & $\begin{array}{c}\text { Overall } \\
\text { Result } \\
\text { (Positive } \\
\text { or } \\
\text { Negative) }\end{array}$ \\
\hline \multirow{7}{*}{18} & $\begin{array}{l}\text { 1. Do you like to edit your peer's } \\
\text { paper? }\end{array}$ & 16 & 02 & Positive \\
\hline & 2. Do you trust the editor? & 13 & 05 & Positive \\
\hline & $\begin{array}{l}\text { 3. Did you learn anything from peer } \\
\text { editing? }\end{array}$ & 15 & 03 & Positive \\
\hline & $\begin{array}{l}\text { 4. Did you face any problems when } \\
\text { you work as editor? }\end{array}$ & 7 & 11 & Positive \\
\hline & $\begin{array}{l}\text { 5. Do you feel that group member } \\
\text { should be changed for each pair editing } \\
\text { session? }\end{array}$ & 13 & 5 & - \\
\hline & $\begin{array}{l}\text { 6. Do you think the shortage of time } \\
\text { may hinder this process? }\end{array}$ & 9 & 9 & Positive \\
\hline & $\begin{array}{l}\text { 7. Do you like to work as peer editor in } \\
\text { regular basis? }\end{array}$ & 16 & 2 & - \\
\hline
\end{tabular}




\section{Peer editing drawbacks and few suggestions:}

Peer feedback is still hotly debated. Various conclusions have been drawn, that is, peer feedback is advantageous in one side and disadvantageous in the other side. The criticism toward peer feedback offered by Hong (2006), that the students devalue peer feedback activity, even, they do not like peer feedback at all. The students, according to Hong, commented that they felt being underestimated by negative feedback given by their peers. But this research revealed that the students have seen peer feedback as an interesting way of learning to write. They also said that comment and negative feedback is the evidence that their writing is really read by their peer. In fact, Peer feedback generates positive impact if the students are ready and well-trained and prepared by the teacher. It can be assumed that peer feedback failure is caused by ignoring this aspect. Generally, peer feedback might be useful to enhance students' awareness on the grammatical mistakes and mechanical mistakes. Students who are not aware of this aspect might use inappropriate tenses in their narrative and peer feedback can stimulate their awareness on this kind of mistake. According to Clark (2003) peer feedback in process oriented narrative writing can be successfully done if the teacher provides guidance. Most students, especially younger and less able writers, need direct instruction in evaluating writing and guidance in responding to the writing of peers. Therefore, the teacher needs to prepare feedback form or narrative rubric to help students doing peer feedback.

\section{Conclusion:}

It appears from the findings that in peer editing process students get a very wide opportunity to learn from editing others papers and from having their papers edited, and therefore the student who becomes good editor generally becomes a good writer. In peer editing process students begin to look at their own papers differently and more critically. However, improving writing skill is a slow process, the positive result of peer editing may not be observed in first few weeks rather may be observed a few weeks later. Hence, if the students are guided properly acquiring the strategy of the editing process surely they become independent writers and editors within a very short period. 


\section{Works Cited}

Clark, Irene. L. (2003). Concepts in composition: theory and practice in the teaching of writing. New Jersey: Lawrence Erlbaum Associates.

Hyland, K. (2003). “Genre-based pedagogies: A social response to process." Journal of Second Language Writing, 12 (1), 17-29.

Min, H-T. (2006). “The effects of trained peer review on EFL students' revision types and writing quality." Journal of Second Language Writing, 15 (2), 113-131.

Richards, C.J \& Lockhart, C. (2000). Reflective Teaching in Second Language Classroom. Cambridge: Cambridge University Press.

Rollinson, P. (2005). “Using peer feedback in the ESL writing class.” ELT Journal, 59 (1), 23-30. doi:10.1093/elt/cci003

Tsui, A. B. M. \& Maria, N.G. (2000). “Do secondary L2 writers benefit from peer comments?" Journal of Second Language Writing, 9 (2), 147-170.

Villamil, O. S. \& De Guerrero, M. (1998). “Assessing the impact of peer revision on L2 writing." Applied Linguistics, 19 (4), 491-514. 


\section{Appendix}

Student's commentaries:

1. I specially found the improvement from draft 1 of $1^{\text {st }}$ paragraph to1st draft of third paragraph and now I am able to write faster than before. I know how to organize the ideas and to write it using appropriate grammatical rules ......

2. The peers in my group commented carefully on my writing which helped me revise my later draft much better than the previous one ........

3. I learned a lot due to the enthusiastic comments from my peers in my group. I also learned new things from reading my peers' essays ......

4. Peer editing helps me to recognize my mistakes .....

5. Peer editing helps us to correct our mistakes before the teacher sees them ...

Teacher's commentaries:

1. It gives students a chance to practice their skills, discuss problems in context and check grammar....

2. Differences in student's opinions may lead to better learning.....

3. It creates a relaxed learning environment.....

4. If student's level is very low, they wouldn't be able to do it...

5. Good for weak students if paired with strong ones.... 